\section{Moss in War-time Medical Dressings}

The position in the War of 1914-18, when the acute shortage of cotton-wool necessitated the widespread use of Sphagnum moss as an absorbent dressing for field wounds, has been anticipated in the present efforts to recommend reserves of this material properly collected and suitably prepared (Lancet, Dec. 14, p. 753). During 1914-18, when the War Office officially sanctioned the use of bog-moss and itself ordered considerable supplies from Dublin and Edinburgh War Dressings Supply Centres, Colonel C. W. Cathcart, of the Edinburgh Royal Infirmary, investigated its properties in comparison with other cheap and easily available absorbants and deodorants like pinewood sawdust and peat moss litter and showed its considerable advantage, even over ordinary eotton-wool (Brit. Med. J., July 24, 1915).

The history of Sphagnum as a wound dressing is, however, older than the War of 1914-18. 'The earliest record is given in Joyce's "History of Ireland", when it was described as used for a wound dressing on the battlefield in the battle of Clonturf in 1014. The first use in medical science was at Kiel, in Germany, last century, when a workman who had lacerated his forearm had it wrapped in peat moss, and he was sent down to Kiel, where he arrived ten days later, and, to the surprise of the medical authorities on removing the moss, the wound had healed most satisfactorily (Neuber : "Erfahrungen über Iodoform under Torf-Verbande", Arch. klin.-Chir., 27, 757; 1882). The first recommendation for its use by the British during the War of 1914-18 was apparently Prof. J. Bailey Balfour's letter to the Scotsman of November 17, 1914, although the pioneer work in medical circles was that of Col. Cathcart. The Canadians and Americans in the later stages of the War were preparing considerable supplies of these dressings for their own troops in the field. In 1916 the Irish material prepared at Dublin reached an output of 20,000 dressings a month, 5,000 of which went to the War Office and the rest to eighty hospitals. The Edinburgh station was supplying 2,000 dressings 8 week for military use without charge.

\section{British Drug Plants}

The wholesale cultivation of drug-producing plants in Great Britain is being encouraged by the Pharmaceutical Society and the Ministry of Agriculture to meet the deficiency of Continental imports, and a medical correspondent in the Lancet of December 7 points out the dangerous position arising from the prohibitively high prices and the acute shortage of necessary drugs. A survey by the Chemist and Druggist of the present conditions on the nine big commercial drug-plant farms in Great Britain reports a fairly good harvest this past season, but considerable extensions will be required to meet the needs of the manufacturing chemists in 1941. The chief plants required, and suitable for wholesale cultivation as field crops, are deadly nightshade (Atropa belladonna), thorn-apple (Datura stramonium), henbane (Hyoscyamus niger), monkshood (Aconitum napellus), foxglove (Digitalis purpurea), hemlock (Conium maculatum), white horehound (Marrubium vulgare), skull-cap (Scutellaria galericulata), male fern (Lastrea Filix-mas), mother-wort (Leonurus cardiaca), chamomile (Anthemis tinctoria), wormwood (Artemisia absinthemum), squirting cucumber (Ecballium elaterium), opirm poppy (Papaver somniferum), and valerian (Valeriana officinalis).

Fortunately, the Ministry of Agriculture's handbook on the subject is an up-to-date work with the experience of the War of 1914-18; but, in addition to cultivating the herb crops, accurate methods of early harvesting and early and slow drying are necessary if the full chemical resources of the plants are to be available. It may also be necessary to cultivate herbs of the Labiates, like lavender (Lavendula vera), rosemary (Rosmarinus officinalis) and wound-wort (Stachys betonica), and some Umbellifers, like angelica (Angelica archangelica), for their essential oils for the perfumery and essential oil trade. Although the position regarding organic dyes is much better than in the War of 1914-18, the return to cultivation of woad (Isatis tinctoria) and other dyeproducing plants is envisaged.

\section{Palæolithic Paintings in the Dordogne}

IN the enthusiasm of fresh discovery, archæologists at times are apt to overstress the importance of their finds. No reservation is necessary in appreciating the outstanding character of the remarkable discovery of the cave and paintings of palæolithic age at Lescaux in the Dordogne valley, recorded by the Abbé Breuil in another column of this issue of NATURE (see p. 11). Although at the time of writing examination of the cave had proceeded no further than would warrant a preliminary report, sufficient of its nature had already been revealed to justify the conclusion in the opinion of the Abbé Breuil that the discovery is of exceptional importance. To quote his own words "as . . . Déchelette called Altamira 'the Sixtine Chapel of Magdalenian art', so Lescaux represents with equal splendour that of the far more ancient Perigordian". In this remarkable cave with its high central hall and galleries, the latter for the most part still unexplored, are more than eighty paintings, chiefly on blocks fallen from the roof, as well as engravings - in the hall superposed upon the paintings, in the galleries unaccompanied-which it has not yet been possible to examine adequately on account of their delicacy.

In the paintings, the Abbé Breuil distinguishes according to character and technique.nine divisions or classes, each depicting characteristically animals or parts of animals, as well as rectangles, combshaped signs and other conventional forms. Reindeer and mammoth notably are absent, while "more unusual" is a composition in which black rhinoceros, bison, and a recumbent human form appear-possibly "a prehistoric drama", and if so a valuable piece of evidence bearing upon the nature of palæolithic belief and ritual. From this evidence the Abbe Breuil draws certain tentative conclusions as regards the age of the engravings and paintings. The stags and oxen show a truly remarkable and unique 